\title{
Ecohydrology as a basis for the sustainable city strategic planning: focus on Lodz, Poland
}

\author{
Iwona Wagner · Maciej Zalewski
}

Published online: 1 September 2009

(C) Springer Science+Business Media B.V. 2009

\section{Introduction}

In the XXI century human aspirations and needs has been amplified by high demographic dynamics of population. It has been expressed by dynamic spatial expansion of cities, characterised by highly diverse patches of urban development and "novel ecosystems". High quality of environment and ecosystem services are important for assuring high quality of life and human health as one of the top priorities for the sustainable city development. Therefore, there is a need for a new paradigm of holistic city management. Cities needs to be considered as ecological systems, where fundamental processes such as water circulation, matter and energy flow are extremely condense (Zalewski and Wagner 2005). Understanding flow paths of these components can help to regulate them and enhance the effectiveness of the Integrated Urban Water Management (IUWM). The efficiency of the environmental resources use in highly impacted urban systems can be increased by understanding

I. Wagner · M. Zalewski

Department of Applied Ecology, University of Lodz, 12/16 Banacha Str., 90-237 Lodz, Poland

e-mail: mzal@biol.uni.lodz.pl

I. Wagner $(\bowtie) \cdot$ M. Zalewski

International Institute of the Polish Academy of Science, European Regional Centre for Ecohydrology under the auspices of UNESCO, 3, Tylna Str., 90-364 Lodz, Poland e-mail: iwwag@biol.uni.lodz.pl interrelations between hydrological and biological processes subjected directly to laws of thermodynamics. Application of this approach through ecohydrology and ecosystem biotechnologies, complementing the traditional engineering solutions has been tested in Lodz - one of the demonstration cities of the EU SWITCH Project (GOCE 018530).

\section{The City of Lodz: it water resources and challenges}

Lodz (800 thousands inhabitants) is the second biggest city in Poland, located in the central part of the country. The city's water resources management is driven by its location on the watershed divide between the two major rivers in Poland: Vistula and Oder. The city area is the source to 18 streams (average flow $<1 \mathrm{~m}^{3} \mathrm{~s}^{-1}$ ), conveying waters towards its outskirts (Fig. 1). Most of the urban streams were channelised and converted into a combined sewerage and stormwater system in the early years of the Twentieth Century, contributing to accelerated water outflow. The dense development of the city also led to reduced ability of the landscape to retain water. All together, this setting created the following challenges to the city:

- increased flooding,

- high flows into the waste water treatment plant (WWTP) during wet weather, lowering efficiency of the facility, 


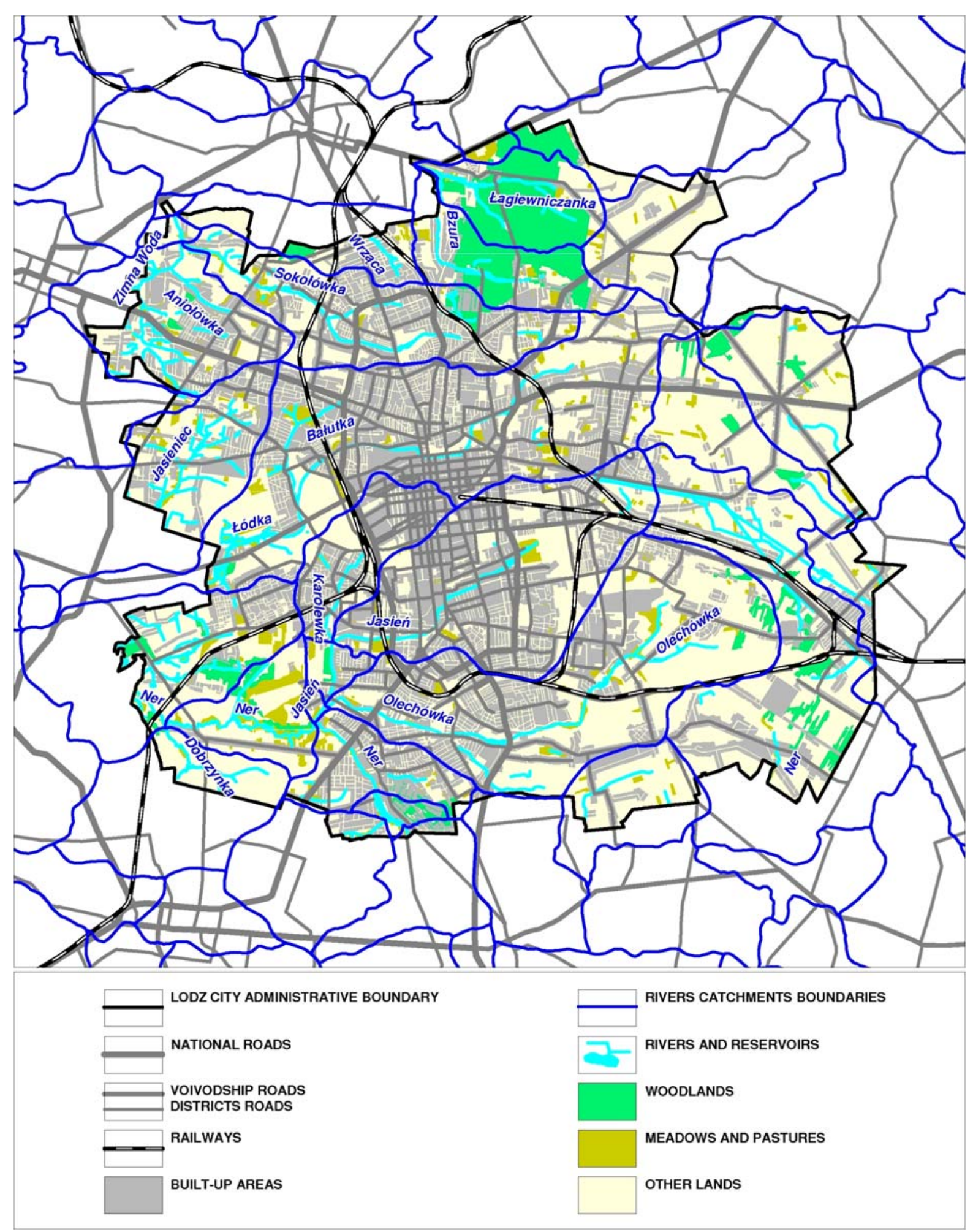

Fig. 1 Streams catchments in the territory of the Lodz City $\left(294 \mathrm{~km}^{2}\right)$ - the Sokolowka (northern part of the city) and Ner rivers (southern part of the city) serve as demonstration areas for implementation of ecohydrology in systemic urban water management (elaborated by: M. Grzelak based on the resources of the Marshal's Office of the Lodz Voivodship) 
- creation of a heat island, low humidity and high concentration of dust and air pollutants during dry weather, due to reduced infiltration and fast stormwater drainage through the sewerage system,

- high hydraulic stress to aquatic ecosystems, due to over-engineering and degradation of the water cycle,

- reduction of aquatic ecosystem capacity for water retention and self-purification, due to simplification of habitats and consequent ecological degradation,

- decreased quality of water for human health, recreational use, aesthetical values and good ecological status.

\section{Ecohydrology: a more sustainable way forward}

Ecohydrology is a transdisciplinary science (Zalewski 2006; Zalewski et al. 1997). It considers interrelations between catchment-as a template for water and nutrient dynamics - on one side, and habitat modification and biological processes-from ecological succession, biological productivity down to nutrients circulation by the microbial loop-on the other. It strives to utilize these interrelationships as a basis for a system management approach, for enhancement of environmental sustainability and capacity against human impact. These are used in risk management (Zalewski 2000), for water quality improvement (e.g., Izydorczyk et al. 2008), biodiversity maintenance (e.g., Agostinho et al. 2004; Chicharo et al. 2001), enhancement of ecosystem services (e.g., Krauze and Wagner 2008) and sustainable development (e.g., Wagner-Lotkowska et al. 2004).

The ecohydrology approach is defined by the three following principles (Zalewski 2002):

- hydrological principle: the hydrological cycle should be considered as the template for quantification of threats (relevant to critical areas of impact) and opportunities (relevant to areas of high biological performance of ecosystems, which can be potentially used for management purposes).

- ecological principle: freshwater ecosystem robustness can be enhanced on the basis of understanding the evolutionary established resistance and/or resilience of the ecosystem.
- ecological engineering principle: enhancement of ecosystem resistance/resilience can be achieved by "dual regulation" of biocoenosis by hydrology, and vice versa (Zalewski 2006).

The fundamental knowledge about particular ecohydrological processes was built for decades (e.g., Eagelson 1982; Naiman et al. 1988; Baird and Wilby 1999; Rodriguez-Iturbe 2000). However, the ecohydrology concept as a holistic framework, which integrates this knowledge for water and environmental sustainability and enhancement of catchment resilience, has been introduced and developed within the UNESCO IHP Programme (Zalewski 2000, 2002; Zalewski et al. 1997). Existing data proves that integrating the new engineering technologies with holistic ecohydrological methods based on current understanding of ecosystem functioning, provides the opportunity to increase efficiency of environmental management and reduces costs of investments in infrastructure. The question that arises in the face of the dynamic global urbanization and climate change is how to translate the experience gained in natural and semi-natural systems to providing systemic solutions for cities and urban areas. The good opportunity to create a new dimension-urban ecohydrology - has been provided by the European Project SWITCH- "Sustainable Water management Improves Tomorrow's Cities' Health" (EU PF6, GOCE 018530) and its implementation in the city of Lodz.

\section{Demonstration projects in Lodz: bringing concepts to reality}

The water management challenges in Lodz are being addressed by two demonstration projects. The first one relates to restoration of a municipal river for stormwater management, increase of water retentiveness, purification, and improvement of quality of life (the demonstration project located on the Sokolowka River). The second one relates to sustainable solutions for the use of sewage sludge in biomass and bioenergy production on willow plantations, and providing additional economic income (the demonstration project located at the protective zone of the WWTP, at the Ner River). Scientific research developed at the demonstration projects provides a basis 
for development of ecohydrology-based system solutions for the city, their implementation, validation and adaptation of the efficiency of the undertaken measures to the local conditions. The research includes the following activities (all the reports available at www.switchurbanwater.eu):

Hydrological monitoring of the Sokolowka river, including installation of the online monitoring stations, which allows for analysis of the water budget and development of mathematical model for the stormwater management. These results, together with the results of large-scale field experiments, allowed for designing a Sedimentary-Biofiltration System for efficient stormwater purification at stormwater outflows. Its constructions enhances allocation of nutrients into un unavailable pool and prevents flushing of pollutants into the river during high flows. The system is under construction and is scheduled for completion in 2009.

Study of ecohydrological relations was a basis for design of two reservoirs, their hydrodynamic adjustment for preventing the appearance of toxic cyanobacterial blooms, and shaping their biotic structures to increase the absorbing capacity against pollution. One of the reservoirs was constructed in 2006, the other one will be finalized in 2009 (Fig. 2).

Landscape validation of the Sokolowka Valley included nature evaluation and mapping of real vegetation as well as assessment of seasonal dynamics of biomass distribution and the phosphorus removal efficiency. It is a basis for the rehabilitation plan of the river valley and creation of the Sokolowka River Park.

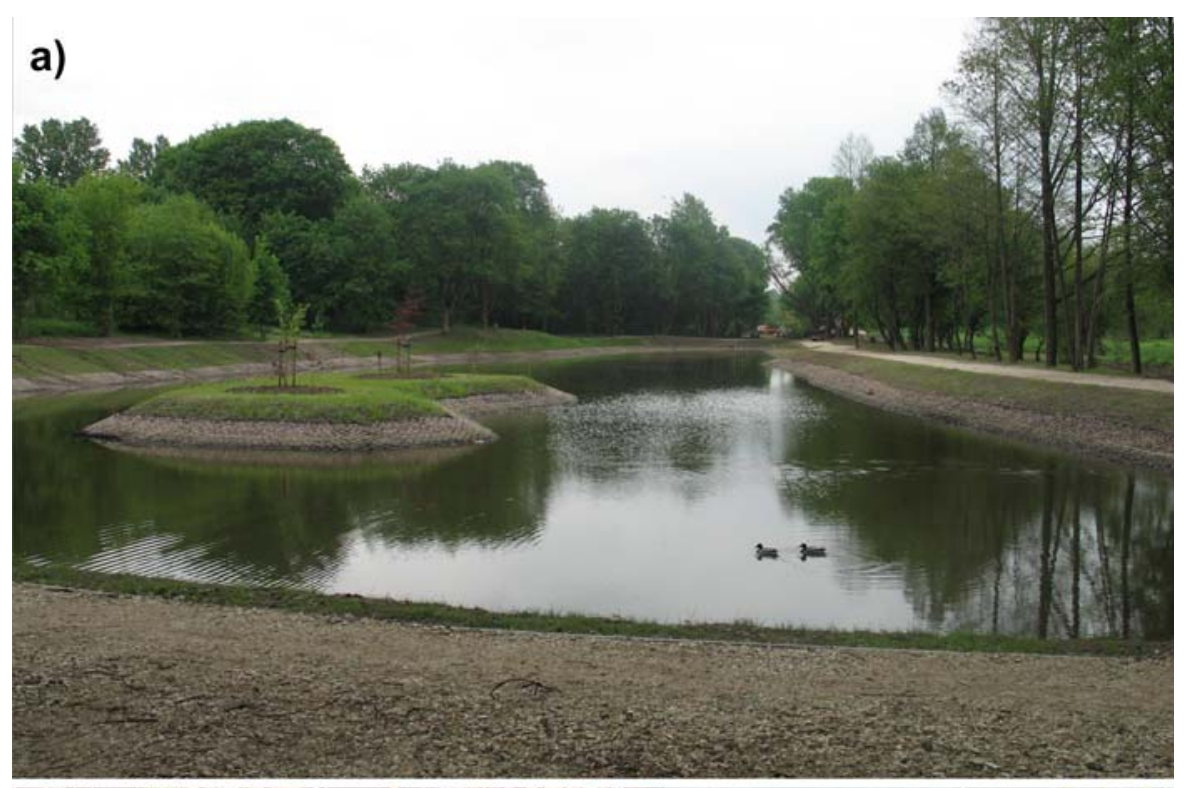

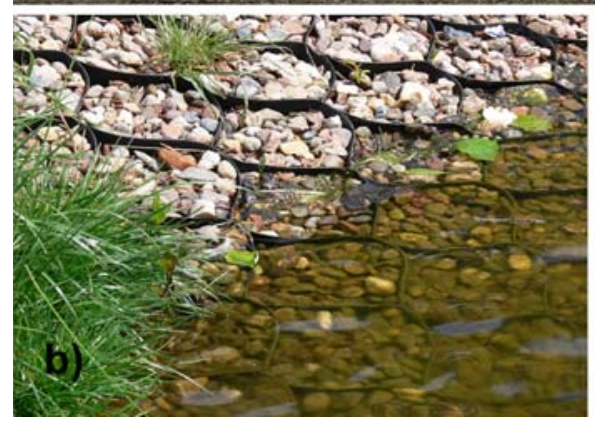

Fig. 2 Enhancement of the absorbing capacity of the Teresa Reservoir (a) in the Sokolowka River cascade to reduce pollution and eutrophication. Adaptation of the bottom structure (b) as an example of implementation of third

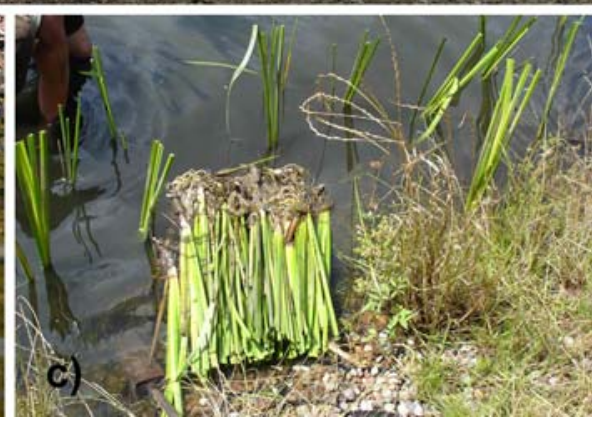

principle of ecohydrology by using phytotechnology (c) to re-allocate nutrients into the unavailable pool for water quality improvement. (Photo credits: a Anita Waack-Zajac, b, c Iwona Wagner) 
Chemical analysis of the seasonal and spatial distribution of PCBs, PCDDs and PCDFs in bottom sediments, biota and water samples (Urbaniak et al. 2008, 2009) as well as dynamics of cyanobacterial blooms toxicity in reservoirs allowed for the basic risk assessment and identification of the sequence of preventive measures in order to provide the required water quality for safe recreational use.

Assessment of fish assemblages was the basis for evaluation of fisheries resources considered as ecological services to the local communities. Additionally, the effect of various degrees of aquatic ecosystems contamination on the fish condition at molecular level was described on the basis of analysis of fish RNA/DNA ratio. The results reveals the RNA/ DNA ratio in fish tissues as a possible indicator in biomonitoring of urban rivers degradation and a screening method for evaluation of contamination of water ecosystems.

Ecological status of the river was assessed based on the system elaborated in the framework of the European Project FAME (EVK1-CT-2001-00094). Additionally, the study considered benthic diatoms and prevailing conditions in relation to trophy and saprobity according to Hofmann (1994) for the reservoirs and Van Dam et al. (1994) in the river classification.

Research on the application of sewage sludge for biomass production resulted after 3 years in elaboration of three methodologies: (1) increasing the yield of bioenergy from willow crops, (2) using stabilized sewage sludge in the deciduous ornamental shrub production and, (3) development of a mathematical model for the Decision Support System for for optimization of sewage sludge use for biomass production, heavy metals removal, calculation of the optimal sludge dose and economical efficiency of the system (Drobniewska 2008, Wagner et al. 2008a).

Ecohydrology and human health. One of the more important recent health problems in large and medium cities, including Lodz, is high appearance of bronchial asthma and allergic diseases. There are convincing data showing, that uncontrolled urbanization changing the environment and microclimate promotes allergic diseases and bronchial asthma, which have been recently considered by WHO as civilization diseases. Among potential environmental factors, urbanization seems to be one of the strongest ones-the highest prevalence of atopic diseases is recorded in the big, modern cities and it is still very low in traditional rural areas (Kuprys-Lipinska et al. 2009).

The overarching goal of all the research activities is to develop a system solution which addresses the complexity of water and water-related issues in Lodz, and help to accomplish sustainable development of the city, based on water resources and ecohydrology as a its fundamental component (Fig. 3).

\subsection{Learning alliances: a way to increase uptake}

The idea of demonstration projects has received great interest and support from the Lodz Learning Alliance (LA) members. Learning Alliance is a group of interconnected players typically including public (e.g., line ministries, utilities, regulators, educators, research institutes), private sector (e.g., industry, financial services), and civil society players (e.g., NGOs, media, professional bodies and unions, advocacy organizations; Morris 2006). The LA group in Lodz was formed in the first phase of the development of the SWITCH project. Significant progress, in both research and implementation, has been achieved by active involvement of the LA into the process of demand-driven research (Batchelor and Butterworth 2008; van der Steen and Howe 2009; Butterworth et al. 2008). It allowed for identification of priority issues to be addressed by the research, including implementation of Best Management Practices in stormwater management (BMPs), application of ecosystem biotechnologies for the restoration of the water cycle and aquatic ecosystem management, and integrated spatial planning of the city for its sustainability.

In order to ensure the efficient implementation of the research results, the LA has been gradually extended with new members, directly involved into the emerging activities. The variety of activities conducted using the Learning Alliance methodology allowed the research and demonstration projects to be widely extended with the aspects addressing the priority issues in the city (Fig. 4). After 3 years of the implementation of SWITCH, the initial demonstration projects have become models for up-scaling in other areas of the city, by both the city management and private investors.

The most evident examples of the new developments are: elaboration of the recommendations for 


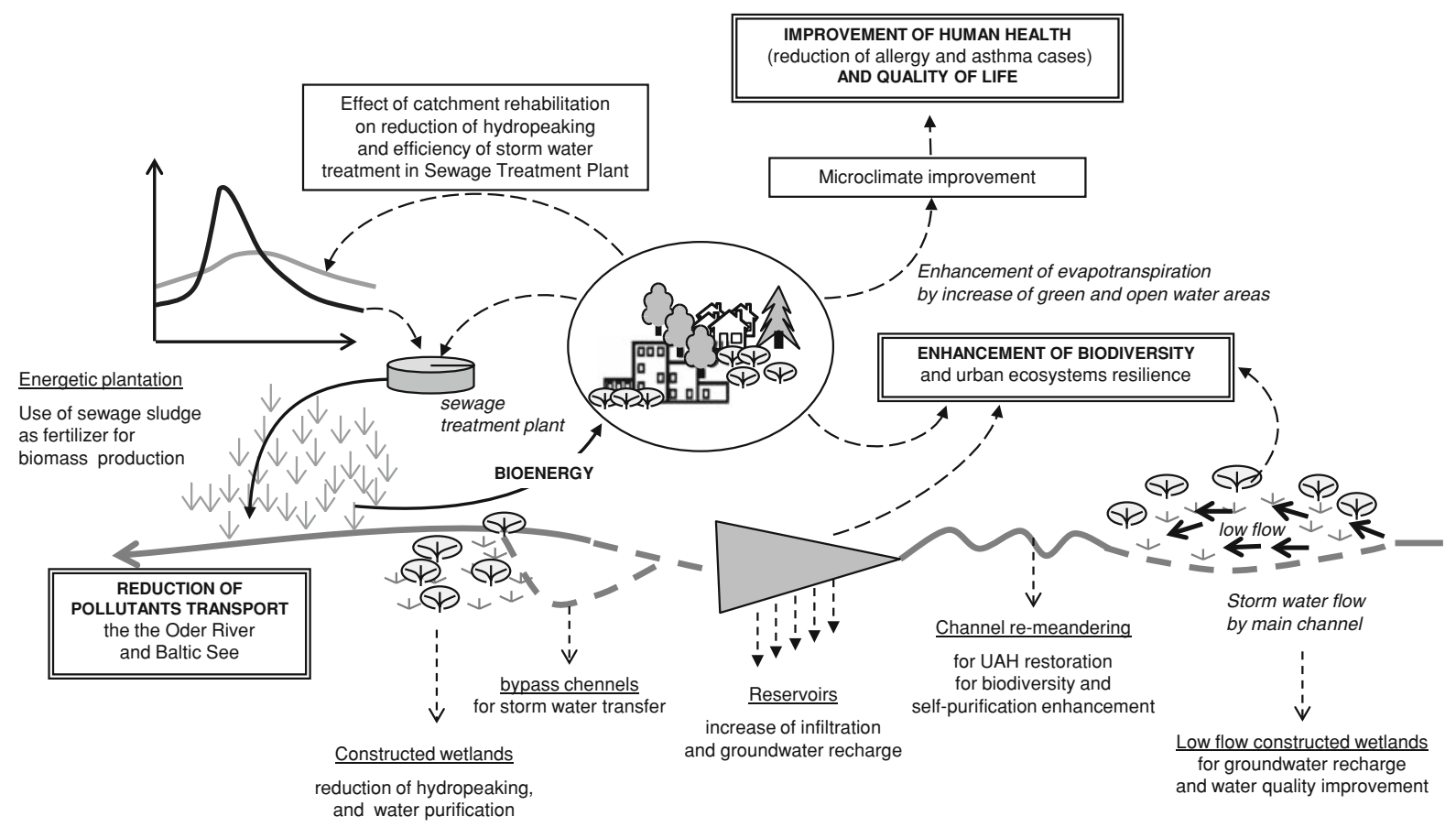

Fig. 3 Rehabilitation of a municipal river: an example of possible multidimensional benefits for the urban environment and the society (Zalewski and Wagner 2008)

protection, management and spatial development for all river corridors in Lodz (in 2007), formulation of recommendations for the Spatial Development of the City with regard to stormwater management (in 2009), formulation of recommendations for the Spatial Development of the City with regard to rivers and green areas (in 2009), and development of the Blue-Green Network concept (in 2009).

Another critical step forward towards more sustainable urban water management was involvement of the Learning Alliance in the process of the strategic planning for the City. In January 2008, a visioning and scenario-building workshop was held, leading to the creation of a common vision for sustainable water management: "LODZ 2038: Lodz uses water wisely" (Box 1). It was agreed by all the participants from executive and managerial levels of stakeholder organizations in the city and regional levels, as well as representatives at the national level.

\subsection{Blue-green network concept}

The "Blue-Green Network" (Zalewski and Wagner, publication under preparation) is a new concept of urban space planning which develops the former idea of a green belt around the city. The Blue-Green Network intends to connect the existing and, where possible, rehabilitated city river system, purified by ecohydrology and ecological technologies and green areas (agricultural areas, parks, wastelands, degraded areas and others) into one functional system, maintaining the continuity of ecological processes within the city. The concept provides a framework for the sustainable development of the city based on its specific hydrological situation and character of water resources. The organisation of the city space according to the Blue-Green Network provides the basis for: (1) stormwater retention and its purification by ecohydrological measures and ecosystem biotechnologies; (2) improvement of microclimate in the city and its flexible adaptation to global climate change; (3) improvement of health of the city inhabitants (e.g., Kuprys-Lipinska et al. 2009); (4) improvement of environmental quality in the urban space and lowering costs of its management (e.g., Revitt et al. 2003); (5) providing conditions for development of zero- $\mathrm{CO}_{2}$-emission public transportation; (6) supporting protection and revitalisation of historical and cultural heritage of the city, and improvement of its attractiveness, aesthetics and the quality of life. The 


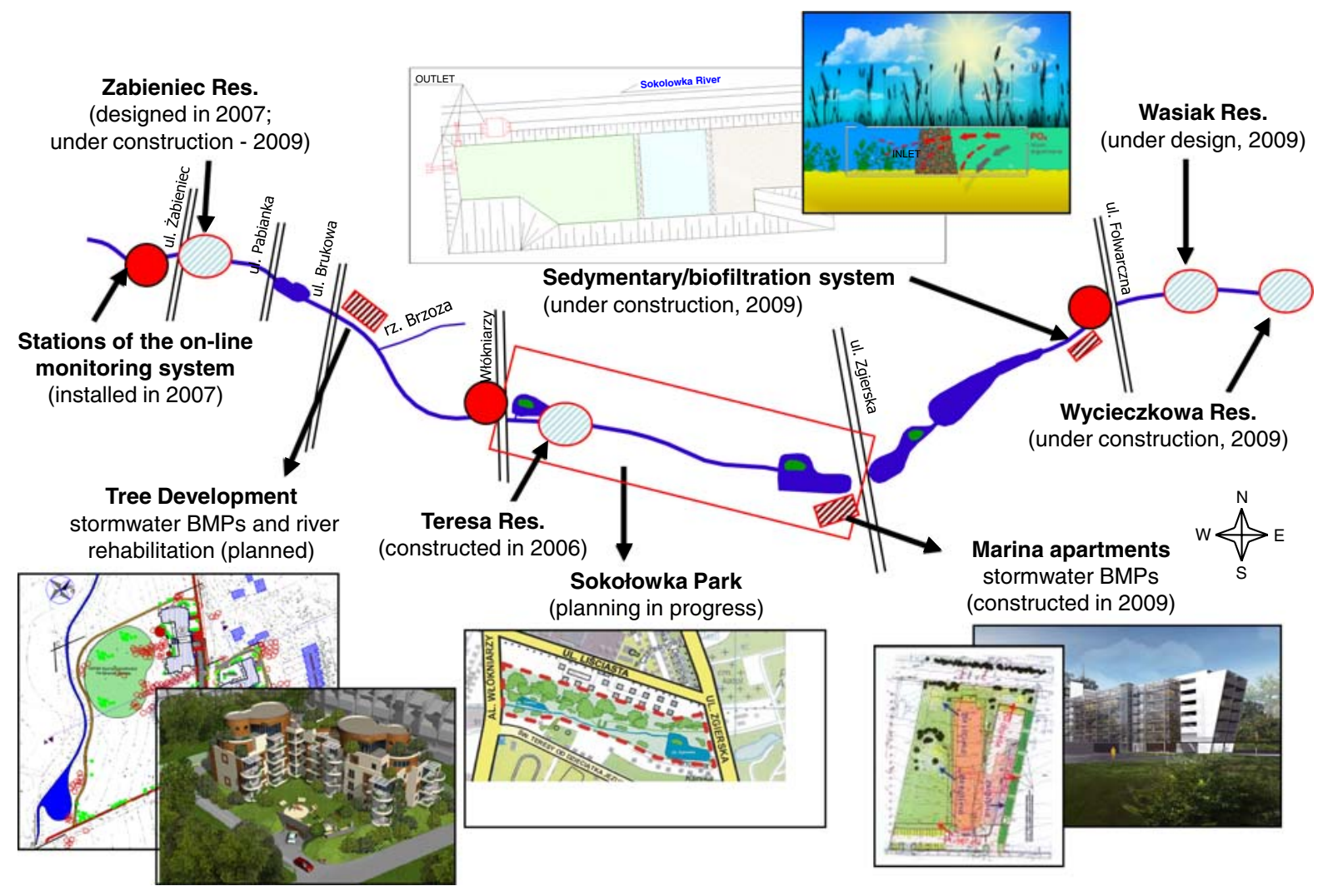

Fig. 4 Advancement of activities carried out at the Demonstration Project on the Sokolowka River

Box 1. Common vision for the integrated urban water management: "LODZ 2038: Lodz uses water wisely", elaborated within the SWITCH project by the Lodz learning alliance group

The city's resources management is based on an efficient and integrated system ensuring access to information for all. Investors and authorities respect ecological properties of land and waters. Infrastructure serves the functions and requirements of an environmentally secure city, is reliable, meets the needs of all the city's population and assures good status of aquatic ecosystems. Green areas-river valleys along open corridors-provide space for recreation and are the 'green lungs' of Lodz. The application of ecological biotechnologies and the population's common and in-depth ecological awareness contributes to an exceptional quality of life. Our city is a leading centre for innovation, education and implementation in Poland

concept has been accepted by the city management and society, as the basis for Lodz sustainable development.

\section{Conclusions}

Intensive urban development inevitably requires quick decisions on spatial organisation. These have a long-term effect not only on the towns' aesthetics and identity, but also on their ecological safety, quality of living and the health of its residents. Intensive, unsustainable development of urban areas has been generally related to landscape degradation due to high density of city infrastructure, excessive increase of impermeable surfaces, reduction of green areas, and river canalisation and simplification, among others. These factors place pressures on the city's environment and microclimate (Zalewski and Wagner 2005), promoting extreme heat and dry air in summers and significant increases of temperature during winters (heat island), and destabilising the thermal pattern in urban areas. Decreased storm water infiltration causes increased flooding during rain events, while accelerated runoff via traditional 
drainage systems results in excessive decreases in air humidity in dry weather. This leads to more dust and air pollution, which in turn promotes allergic diseases of the respiratory system such as allergic rhinitis and atopic bronchial asthma (Kuprys-Lipinska et al. 2009), and respiratory and vascular systems disorders (e.g., Pope and Dockery 2006; Morgenstern et al. 2007). Destabilization of the urban water cycle leads also to further degradation of water and water-related ecosystems, through hydraulic stress, habitat degradation and physical and chemical pollution, lowering their health and ecological status. These conditions raise doubts as to whether the European Directives on environmental issues (e.g., Water Framework Directive, 2000/60/EC) as well as Millennium Development Goals of the United Nations (Wagner et al. 2008b) can be achieved on time.

In European cities, society has increasing expectations regarding the quality of life. It goes nowadays far beyond the access to basic services, and becomes dependent to a large extend on healthy environment. This relay in turn on proper distribution and functioning of water and land ecosystems and their ability to provide ecosystem services.

Finally, open water and green areas, if properly distributed within the city boundaries, are means of conveying aesthetic and cultural values and enable recreation for the city inhabitants are which is crucial for proper psycho-physical regeneration in a dynamically developing society.

Considering the above, as well as the location and hydrological specifics of Lodz, river valleys and green areas should become axis for the city functional spatial organisation, and basis for the strategy for its sustainable development in the face of global change.

Acknowledgments Acknowledgments to the research team of SWITCH Lodz, contributing to particular aspects of the project. The researchers are working in the Department of Applied Ecology, University of Lodz and International Institute of Polish Academy of Sciences-European Regional Centre for Ecohydrology under the auspices of UNESCO, unless indicated otherwise: Biological and toxicological assessment and monitoring: Jonna Mankiewicz, Katarzyna Izydorczyk, Joanna Zelazna-Wieczorek (Department of Algology and Mycology University of Lodz), Agnieszka Bednarek, Adrianna Wojtal-Frankiewicz, Tomasz Jurczak, Zbyszek Kaczkowski, Magdalena Urbaniak, Maja Godowska, Ilona Gagała, Marek Ubraniak; Hydrological processes: Wojciech Frątczak; Marek Zawilski and Grazyna Sakson (Department of Environmental Engineering Subdepartment of Water and Sewage Technology, Technical University of Lodz);
Adam Bartnik and Przemysław Tomalski (Department of Hydrology and Water Resources, University of Lodz); Bioenergy: Agata Drobniewska; Landscape and river valley vegetation: Kinga Krauze, Edyta Kiedrzynska; Józef Kurowski, Marcn Kiedrzynski, Piotr Witoslawski (Department of Geobotanic and Plant Ecology, University of Lodz); Human Heath: Piotr Kuna, Izabela Kupryś-Lipińska (Department of Internal Medicine, Asthma and Allergy, Norbert Barlicki Memorial Teaching Hospital No. 1, Medical University of Lodz); Nofer Institute of Occupational Medicine in Lodz; Learning Alliance: Monika Dzięgielewska-Geitz, Łukasz Kamiński, The City of Lodz is a proposed platform of Long-Term Socio-Ecological Research (LTSER) of the European Long-Term Ecosystem Research Network.

\section{References}

Agostinho AA, Gomes LC, Verissimo S, Okada EK (2004) Flood regime, dam regulation and fish in the Upper Parana' River: effects on assemblage attributes, reproduction and recruitment. Rev Fish Biol Fisheries 14:11-19

Baird AJ, Wilby RL (eds) (1999) Eco-hydrology. Plants and water in terrestrial and aquatic environments. Routledge, London, New York

Batchelor C, Butterworth J (2008) Scenario building. SWITCH learning alliance briefing Note 11. http://www.switchur banwater.eu/outputs/results.php?wp_select=17\&pubtype_ select=1\&op2_select=\&pt=Learning\%20Alliance $\% 20$ Bri efing $\% 20$ Notes \&m $=0,6,1,1$

Butterworth JA, Dziegielewska-Geitz M, Wagner I, Sutherland A, Manning N, Da Silva C, Verhagen J (2008) Learning alliances for innovation in urban water management. Paper presented at the thematic workshop Water and Cities workshop, Water Tribune Expo Zaragoza, 25-28 July 2008

Chicharo L, Chícharo MA, Esteves E, Andrade P, Morais P (2001) Effects of alterations in fresh water supply on the abundance and distribution of Engraulis encrasicolus in the Guadiana estuary and adjacent coastal areas of south Portugal. Ecohydrol Hydrobiol (3):341-345

Drobniewska A (2008) Optimization of the use of sewage sludge for bioenergy production based on a large scale experimental willow plantation and mathematical model. Ph.D. thesis, University of Lodz

Eagelson PS (1982) Ecological optimality in water limited natural soil-vegetation systems. 1. Theory and hypothesis. Water Resour Res 18:325-340

Hofmann, G (1994) Aufwuchs. Diatomeen in Seen und ihre Eignung als Indikatoren der Trophie. Bibl Diatomol $30: 241$

Izydorczyk K, Jurczak T, Wojtal-Frankiewicz A, Skowron A, Mankiewicz-Boczek J, Tarczyńska M (2008) Influence of abiotic and biotic factors on microcystin content in Microcystis aeruginosa cells in a eutrophic temperate reservoir. J Plankton Res 30(4):393-400

Krauze K, Wagner I (2008) An ecohydrological approach for the protection and enhancement of ecosystem services. In: Petrosillo I, Jones B, Muller F, Zurlini G, Krauze K, Victorov $S$ (eds) Use of landscape sciences for the 
assessment of environmental security. Springer, Berlin, pp 177-207

Kuprys-Lipinska I, Elgalal A, Kupczyk M, Bochenska-Marciniak M, Kuna P (2009) Urban-rural differences in the prevalence of atopic diseases in Lodz province (Poland). Abstrakt book, XXIII EAACI congress, 12-16 June 2004, Amsterdam (in press)

Morgenstern V, Zutavern A, Cyrys J, Brockow I, Gehring U, Koletzko S, Bauer CP, Reinhardt D, Wichmann HE, Heinrich J (2007) Respiratory health and individual estimated exposure to traffic-related air pollutants in a cohort of young children: occupation. Environ Med 64:8-16

Morris M (2006) Learning alliance briefing note no 1: an introduction to learning alliances. SWITCH briefing notes. www.switchurbanwater.eu

Naiman RJ, Decamps H, Pastor J, Johnston CA (1988) The potential importance of boundaries to fluvial ecosystems. J North Am Benthol Soc 7:289-306

Pope AC, Dockery DW (2006) Heath effects of fine particulate air pollution: lines that connect: ISSN 1047-3289. Air Waste Mange Assoc 56:709-742

Revitt DM, Ellis JB, Scholes L (2003) Review of the use of stormwater BMPs in Europe. Report 5.1. EU 5th framework daywater project (www.daywater.org)

Rodriguez-Iturbe I (2000) Ecohydrology: a hydrological perspective of climate-soil-vegetation dynamics. Water Resour Res 36:3-9

Urbaniak M, Zieliński M, Wesołowski W, Zalewski M (2008) PCBs and heavy metals contamination in bottom sediments from three reservoirs of different catchment characteristics. Polish J Environ Stud (6):941-949

Urbaniak M, Zieliński M, Wesołowski W, Zalewski M (2009) Polychlorinated dibenzo- $p$-dioxins (PCDDs) and polychlorinated dibenzo- $p$-furans (PCDFs) compounds in sediments of two shallow reservoirs in Central Poland. Arch Environ Prot 35(2):125-132

van Dam H, Mertens A, Sinkeldam J (1994) A coded checklist and ecological indicator values of freshwater diatoms from the Netherlands. Netherlands $J$ Aquat Ecol 28(1):117-133

van der Steen P, Howe C (2009) Managing water in the city of the future; strategic planning and science. Rev Environ Sci Biotechnol 8:115-120
Wagner I, Bocian J, Zalewski M (2008a) The ecohydrological dimension of small urban river management for stormwater and pollution loads mitigation: Lodz, Poland. In: Wagner I, Marshalek J, Breil P (eds) Aquatic habitats in sustainable urban water management: science, policy and practice. Taylor and Francis/Balkema, Leiden, pp 145-175

Wagner I, Marshalek J, Breil P (eds) (2008b) Aquatic habitats in sustainable urban water management: science, policy and practice. Leiden, Taylor and Francis/Balkema

Wagner-Lotkowska I, Bocian J, Pypaert P, Santiago-Fandino V, Zalewski M (2004) Environment and economy-dual benefit of ecohydrology and phytotechnology in water resources management: Pilica River demonstration project under the auspices of UNESCO and UNEP. Ecol Hydrobiol (3):345-352

Zalewski M (2000) Ecohydrology. The scientific background to use ecosystem properties as management tools toward sustainability of water resources. Ecol Eng (16):1-8 (guest editorial)

Zalewski M (2002) Ecohydrology - the use of ecological and hydrological processes for sustainable management of water resources. Hydrol Sci J 47(5):825-834

Zalewski M (2006) Ecohydrology - an interdisciplinary tool for integrated protection and management of water bodies. Arch Hydrobiol (Suppl 158/4):613-622

Zalewski M, Wagner I (2005) Ecohydrology - the use of water and ecosystem processes for healthy urban environments. Ecohydrol Hydrobiol (4): 263-268 (Special issue: aquatic habitats in integrated urban water management)

Zalewski M, Wagner I (2008) Ecohydrology of urban aquatic ecosystems for healthy cities. In: Wagner I, Marshalek J, Breil P (eds) Aquatic habitats in sustainable urban water management: science, policy and practice. Taylor and Francis/Balkema, Leiden, pp 95-106

Zalewski M, Janauer GA, Jolankai G (eds) (1997) Ecohydrology: a new paradigm for the sustainable use of aquatic resources. UNESCO, Paris (Technical Documents in Hydrology 7) 